\title{
Cinna, Calvus, and the Ciris
}

\section{Citation}

Thomas, Richard F. 1981. Cinna, Calvus, and the Ciris. Classical Quarterly 31(2): 371-374.

\section{Published Version}

doi:10.1017/S000983880000968X

\section{Permanent link}

http://nrs.harvard.edu/urn-3:HUL.InstRepos:3775757

\section{Terms of Use}

This article was downloaded from Harvard University's DASH repository, and is made available under the terms and conditions applicable to Other Posted Material, as set forth at http:// nrs.harvard.edu/urn-3:HUL.InstRepos:dash.current.terms-of-use\#LAA

\section{Share Your Story}

The Harvard community has made this article openly available.

Please share how this access benefits you. Submit a story.

\section{Accessibility}




\section{CINNA, CALVUS, AND THE CIRIS}

Among other things, R. O. A. M. Lyne's recent edition and commentary of the Ciris (Cambridge, 1978) has established the general method of composition followed by this pseudo-neoteric poet: he demonstrably lifted wholesale and applied to his own poem words, phrases, lines, and even entire sequences from the works of the neoterics and the poets of the following generation. ${ }^{1}$ Accordingly, one of the poem's chief attributes is that it serves as a means for recovering the general content, and at times the actual wording, of earlier, more important poetry. This paper offers some additional areas in the Ciris where such influence may exist. I confine myself to Cinna and Calvus, whose poetry may justly be considered the missing two-thirds of the neoteric movement. $^{2}$

\section{CINNA}

I

caeruleas sua furta prius testatur ad umbras; nam qua se ad patrium tendebat semita limen, vestibulo in thalami paulum remoratur et alte suspicit ad $\dagger$ caeli $\dagger$ nictantia sidera mundi, non accepta piis promittens munera divis.

(Cir. 215-19)

Scylla is approaching her father's bedroom, intent on stealing his magical lock, and admitting as much to the night sky. As has been amply demonstrated, ${ }^{3}$ the sequence to which these lines belong (the 'Nurse Scene', 206-385) is almost certainly indebted to, and in parts probably plagiarized from, a similar scene in Cinna's lost epyllion, the Zmyrna. In this context the precise nature of these particular lines has not been investigated.

I begin with a question: what business has Scylla in telling the night of her theft? Lyne correctly refers to examples of such an address occurring in fifth-century Attic drama $;{ }^{4}$ but this is only the beginning of a long tradition. More relevant are instances from New Comedy, Greek Epigram and Roman Comedy, all in the context of amatory á $\rho v \pi v i a$, and usually in the setting of a paraclausithyron: ${ }^{5}$

1 With this poem it is a matter not merely of a poet's re-shaping literary tradition, but rather, to use Lyne's term (p. 47), of 'pillaging'. Since the Ciris is so grossly derivative, there is complete justification for suspecting, and indeed for seeking, elements which may belong to other poetic contexts. For all of this, see Lyne pp. 36-7.

2 The day when such expressions needed an accompanying apology is now past. Although it is true that other poets (e.g. Valerius Cato or Cornificius) may qualify for this title, as Lyne has noted ('The Neoteric Poets', $C Q$ n.s. 28 (1978), 171), programmatic reference to Cinna and Calvus in the poetry of Catullus 'suggests an identifiably Callimachean faction of Catullus, Cinna, and I think Calvus'.

${ }^{3}$ By S. Sudhaus, 'Die Ciris und das römische Epyllion', Hermes 42 (1907), 487 ff.; W. Ehlers, 'Die Ciris und ihr Original', $M H 11$ (1954), 81-2; Lyne, Ciris, Introduction, pp. 40-4; also on lines 274, 324-5, 342-3.

${ }^{4}$ Eur. Elec. 54, Andromeda fr. 114N, Hec. 68-72.

5 Other examples abound; for these see R. F. Thomas, 'New Comedy, Callimachus, and Roman Poetry', HSCP 83 (1979), 183-4, 195-206. 


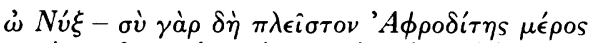

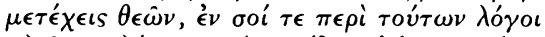

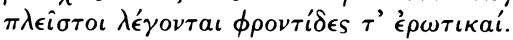

(Men. Misoum. A1 - A3)

"A

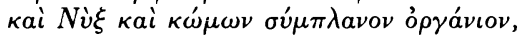

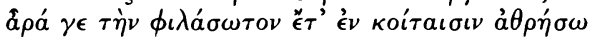

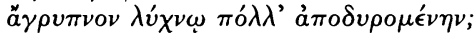

(Meleager, A.P. 5. 191.1-4)

non ego item facio ut alios in comoediis

$\langle v i\rangle$ vidi amoris facere, qui aut Nocti aut Dii

aut Soli aut Lunae miserias narrant suas.

(Plaut. Merc. 3-5)

Cinna was certainly familiar with this tradition; for, as we know, he drew from Callimachus' poetic application of it:

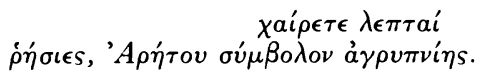

(Callim. Ep. 27. 3-4)

haec tibi Arateis multum invigilata lucernis ${ }^{6}$

carmina.

(Cinna, fr. 11. 1-2 Morel)

I suggest that at $\mathrm{Cir}$. 215-19 we have the remnants of a compressed paraclausithyron, specifically that of Cinna's heroine before her father's chamber (qua se ad patrium tendebat semita limen | vestibulo in thalami paulum remoratur, 216-17). In such a setting the address to Night (caeruleas sua furta prius testatur ad umbras, 215), rather pointless in the Ciris, would make perfect sense. I suspect this entire line is Cinna's, furta originally referring not to any real theft, but to Zmyrna's imminent clandestine affair with her father - perhaps the primary meaning of the word in this type of poetry. ${ }^{7}$

In support of this suggestion it may be noted that Ovid's Myrrha, although not actually before Cinyras' door, also suffers from á $\gamma \rho v \pi v i ́ a$ (Met. 10. 368-82; cf. 369, pervigil). Finally, it would be a typically neoteric touch to have Zmyrna deliver the conventional address of the lover to Night in a totally original setting - before her own father's door.

II

tabidulamque videt labi per viscera mortem

Scylla is wasting away with love. As Lyne observes, tabidulus is both striking and original (the word occurs nowhere else). Elsewhere, conveying the same sense, and again in the Nurse Scene, we find tabescere (249), which is in turn followed closely by tabis (254). Lyne, as had Sudhaus, sees Cinna at this last instance, which is certainly correct. $^{8}$ In the light of this, it seems reasonable to suggest that the metaphor existed in Cinna's poem, and that the unusual diminutive was his coinage. This is supported

${ }^{6} \lambda v_{\chi} \chi v o \iota$, familiar in the setting of amatory á $\gamma \rho v \pi v i a$, are absent from Callimachus' lines; the presence of lucernis in Cinna's version may stand as his acknowledgement of the tradition from which Callimachus drew.

7 Of the numerous examples (ThLL 6. 1649. 68 ff.; also s.v. furtivus, 6. 1644. 42 ff.), the following will suffice: Cat. 68.136 (of Lesbia's lapses), 140 (of Jupiter's); perhaps most suggestive is Virg. Aen. 4. 171-2: nec iam furtivum Dido meditatur amorem: | coniugium vocat, hoc praetexit nomine culpam.

${ }^{8}$ Lyne notes (Cir. ad loc.) that the genitive tabis is rare, and reports Charisius' observation: Cinna autem in Zmyrna huius tabis dixit nullo auctore (Gram. Lat. 193. 25 = Cinna, p. 89 Morel). 
by the fact that all the 'meaningful' diminutives of the $\operatorname{Ciris}^{9}$ (i.e. excepting those which through constant use lost their diminutive force; ocellus, labellum $)^{10}$ appear in passages which have, at one time or another, been suspected of being derived from neoteric verse.

iam fessae tandem fugiunt de corpore vires et caput inflexa lentum cervice recumbit, marmorea adductis livescunt bracchia nodis.

(Cir. 448-50)

Scylla's arms, as she is towed behind Minos' boat, are chafed by the ropes. A tentative suggestion: read nodis arboreally, and with minimal changes (e.g. marmorea obductis durescunt bracchia nodis) we have, at line 450, (Zmyrna's?) metamorphosis. This would perhaps be overly fanciful without the following parallels: Myrrha...obducto cortice pressa latet, Ov. A.A. 1. 285-6; again of Ovid's Myrrha: in magnos bracchia ramos|...duratur cortice pellis, Met. 10. 493-4; of Scylla's actual transformation: marmoreum volucri vestivit tegmine corpus|lentaque perpetuas fuderunt bracchia pennas, Cir. 503-4; lastly, of a tree, the collocation (in this same metrical position) bracchia nodo, Aetn. 364.

\section{CALVUS}

\section{I}

(heu quotiens mirata novos expalluit artus ipsa suos, quotiens heu pertimuit latratus)

Tyndaridae niveos mirantur virginis artus

On the basis of parallels in Ovid ${ }^{11}$ Lyne suggests that the first of these may have its source in the $I o$; on the second (there should be a cross-reference) he notes: 'The source is very possibly Catull. 64 . 364 bustum | excipiet niveos perculsae virginis artus.' While this is quite possible, I suspect the two have a single common source, which is, indeed, the Io. For consider Virgil's well-known lines:
a, virgo infelix, quae te dementia cepit!
Proetides implerunt falsis mugitibus agros, at non tam turpis pecudum tamen ulla secuta concubitus, quamvis collo timuisset aratrum et saepe in levi quaesisset cornua fronte.
a! virgo infelix, tu nunc in montibus erras.

(Ecl. 6. 47-52)

We know, of course, that the first halves of the opening and closing lines of this 'panel' (a, virgo infelix) are from the $I o$ (fr. 9 Morel) ${ }^{12}$ Virgil altered heifers, but Calvus' heroine is supposed to come to the reader's mind. Now in the two lines preceding and following these two (46 and 53) Virgil artfully used the adjective niveus (both in the same metrical position as at Cir. 399) as an epithet of bovine description. I have no

\footnotetext{
${ }^{9}$ For a useful compilation and discussion of the poem's diminutives, together with other notable stylistic features of the poem, see Lyne, Ciris, Introduction, pp. 25-31 ('Style').

10 Generally, on diminutives in neoteric verse, D. O. Ross, Style and Tradition in Catullus (Cambridge, Mass., 1969), pp. 22-6.

11 Her. 14. 89 ff. (of Io), Met. 1. $635 \mathrm{ff}$. (of Io), Met. 14. $59 \mathrm{ff}$. (of Scylla the monster).

12 On the extent to which Virgil reworked the line of Calvus, see Thomas, 'Theocritus, Calvus and the Sixth Eclogue', CP 74 (1979), 337-9.
} 
doubt that Calvus used the word to describe Io the heifer, ${ }^{13}$ and little doubt that behind the phrase niveos mirantur virginis artus at Cir. 399 stand her transformed limbs, which are therefore an object of wonder. ${ }^{14}$

II

a virgo infelix, herbis pasceris amaris

(Calvus, fr. 9 Morel)

Infelix appears in the Ciris seven times, three times at the beginning of the line in the expression infelix virgo $(71,167,517)$, and four times (without virgo, but always in reference to the heroine's plight) in the same position as the example from Calvus ( 155 , $190,318,402)$. Three of these, moreover, are preceded by the same elision that occurs in the line from the Io. The opposite word, felix, appears three times, all in a tricolon abundans at Cir. 27-8: felix illa dies, felix et dicitur annus, | felices qui talem annum videre diemque. Lyne has convincingly argued that the passage in which this couplet occurs is largely lifted from the Io, and that the specific phrase felix illa dies is Calvus' own. ${ }^{15}$ The tricolon will presumably have referred to Io's happier days as priestess of Juno. ${ }^{16}$ Taking all this together, it seems plausible to suggest that Calvus made much of the contrast between his heroine's more fortunate past (felix) and her subsequent situation (infelix).

But what of the actual collocation in the Ciris - infelix virgo? Did Cinna use it? Ovid's Myrrha is described (over two lines, Met. 10. 443-4) as infelix...virgo. If the phrase did appear in the Zmyrna (and this is of necessity speculative) it may be that the variants in the Ciris reflect a 'rivalry' of sorts between Calvus (a virgo infelix) and Cinna (infelix virgo). ${ }^{17}$

\section{Harvard University}

\section{RICHARD F. THOMAS}

13 At least by Ovid's time Io is consistently considered to have been white in colour. This detail in fact appears as early as Acusilaus of Argos (ap. [Apollod.] Bibl. 2. 1. $3=$ FGH 2 fr. 26): $\epsilon$ is $\delta \dot{\epsilon} \beta o \hat{v} \nu \mu \epsilon \tau \epsilon \mu o ́ \rho \phi \omega \sigma \epsilon \lambda \epsilon v \kappa \dot{\eta} \nu$. There were, however, variants, reflected in the Suda (s.v. Isis,

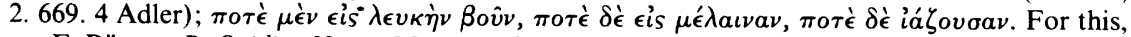
see F. Bömer, P. Ovidius Naso: Metamorphosen I-III (Heidelberg, 1969), ad 1. 610; he suggests solidification of the detail may have been Ovid's contribution, but its presence in Calvus' epyllion would also have ensured dissemination.

14 In 399 , then, as in 81 , miror would carry a more sinister force: 'marvel at the strangeness of' (cf. 81, novos, 'new and strange'). It can have such a force, particularly in this type of poetry: aequoreae monstrum Nereides admirantes, Cat. 64. 15; mirantur et undae, | miratur nemus insuetum fulgentia longe $\mid$ scuta virum fluvio pictasque innare carinas, Virg. Aen. 8.91-3. In neither of these is there any sense of admiration; rather one of surprise at a new and unexperienced phenomenon. Since the context we claim for the Ciris is one of surprise at a transformed object, a third parallel is particularly relevant: Virg. Geo. 2. 82 (of a tree which has suffered grafting and subsequent transformation), miratastque novas frondes et non sua poma.

15 Ciris, ad loc. I suspect, in fact, that the whole couplet is Calvus'; it is just too good: in addition to the chiasmus noted by Lyne (dies...annus...annum...diem), there is the artful repetition in the second line (felices... annum...diemque). All of this in a strictly expanding tricolon, which Calvus (if, indeed, the couplet is his) will have perfected in his capacity as an orator. In this connection, Cicero's comments on him (Brut. 283) are not irrelevant.

16 Probably as early as Hesiod (fr. 125 Merkelbach and West), and at least by the time of Callimachus (fr. inc. sed. $769 \mathrm{Pf}$.), Io is given the epithet $K a \lambda \lambda_{\iota} \theta \dot{v} \epsilon \sigma \sigma \alpha$. Whatever the precise meaning of the word (it appears only in the supplement of $L S J^{9}$ and is given no translation), the suggestion seems to be that Io was in some way a successful priestess; cf. Anth. Pal. 6. 240,

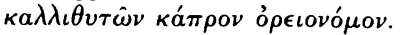

17 A possible reflection of this: Virgil used infelix (nom. or voc.) of Dido six times, three times in each of these two positions (Aen. 1. 749, 4. 68, 4. 450, 4. 529, 4. 596, 6. 450).

I am grateful for comments from my colleagues Professors W. V. Clausen and A. Henrichs who read these notes in draft. 